\title{
Civilisations
}

Revue internationale d'anthropologie et de sciences

humaines

49 | 2002

Pain, fours et foyers des temps passés

\section{Ovens in the early Medieval settlements of South- Western Slovakia}

\section{Matej Ruttkay}

\section{(2) OpenEdition \\ Journals}

Édition électronique

URL : http://journals.openedition.org/civilisations/1805

DOI : 10.4000/civilisations. 1805

ISSN : 2032-0442

\section{Éditeur}

Institut de sociologie de l'Université Libre de Bruxelles

\section{Édition imprimée}

Date de publication : 3 juin 2002

Pagination : 271-283

ISBN : 0009-8140

ISSN : 0009-8140

Référence électronique

Matej Ruttkay, "Ovens in the early Medieval settlements of South-Western Slovakia », Civilisations [En ligne], 49 | 2002, mis en ligne le 01 juin 2005, consulté le 21 avril 2019. URL : http:// journals.openedition.org/civilisations/1805; DOI : 10.4000/civilisations.1805

Ce document a été généré automatiquement le 21 avril 2019

(c) Tous droits réservés 


\title{
Ovens in the early Medieval settlements of South-Western Slovakia
}

\author{
Matej Ruttkay
}

\section{Introduction}

1 Among the frequent findings in the settlements of the early Middle Ages in South-West Slovakia different types of heating devices (open fireplaces and ovens) can be found. These are situated either directly inside the dwellings or outside them.

2 A more detailed understanding of their function and development is a contribution to the elucidation of the way of life of medieval people. The types of oven or fireplace and their location reflect the way and the level of farming, the achieved social position of their builders, as well as historical and cultural specifications, significantly dependant on geographical and climatic conditions and on the value of the soil (Skružny 1980, p. 221, Pražák 1966, p. 324). In specific cases it is also possible to discern, on the basis of certain facts, the ethnical identity of the users or builders, or to specify certain cultural influences.

3 The positioning of a heating device in a settlement object was conditioned by its function and also, to a large extent, by tradition. The function was thought over at the beginning of the construction of the object, determining thus the position (or absence) of the heating device.

4 A great part of the questions connected with the function of ovens has already been cleared up, especially by the works of L. Skružny (1963, p. 234 -265, 1980, p. 221 -242) and A. Pitterová (1971, s. 11 -18). The results of the ethnographic investigation (Švecová 1968, p. 119 -166, Plessingerová 1963, p. $149-235$, Langer 1987, p. 233 -234) are an immense source of information, though the ethnographical observations from the $18^{\text {th }}-20^{\text {th }}$ centuries cannot be automatically applied to the period of the early Middle Ages, because of different social environment, different climatic conditions etc. 

occurred in the early Middle Ages - ovens, i. e. covered fireplaces (made of stone, clay or a combination of the two) and open fireplaces - the remnants of an open fire. Each of these two groups can be further divided according to the construction, function and position within the object or within the settlement. Different types are often found together and this means that it is necessary to assess them in mutual correlation. A too detailed constructional classification of heating devices is not essential for the determination of their function.

\section{Analysis}

7 In dwellings of the $9^{\text {th }}$ to the $11^{\text {th }}$ century (mainly one-roomed) both open fireplaces and ovens are found.

\subsection{Open fireplaces}

8 Open fireplaces belong to the very frequent findings (Hanuliak 1989, p. 164, Habovštiak 1985 , p. $87-100$ ), and it is not always possible to decide unambiguously whether they are not the remnants of a disassembled oven, while the material - stone - was used for the building of a new oven. Fireplaces are usually placed in one corner of a dwelling or in its centre. Fireplaces are mostly surrounded by stones (Ruttkay 1989), and sometimes sunk/ dug (Hanuliak 1989, p. 164), but most frequently directly on the floor (Tocík 1980, Fig. 145, 1, 2), or placed on an elevated base.

9 The opinion that it is impossible to place a fireplace into the corner of a dwelling or near a wall, has been proved to be unjustified (Skružny 1983, p. 223). The placing of an open fire in the corner is supported by many ethnographic parallels (isolation of a wooden wall with a stone plate or with a clay lining) (Plessingerová, 1963, p. 161 - 163).

10 It is interesting that the occurrence of open fireplaces starts to increase from the $11^{\text {th }}$ century onwards. They are frequently found in the period of the top and late Middle Ages, and in the folk architecture they were preserved almost up to now, especially in seasonal dwellings (Ruttkay 1989; Plessingerová 1963, p. 161 -164). The boom in the use of open fireplaces in the $10^{\text {th }}$ century is most remarkably documented by the results of the investigations carried out in Chæaba. In the dwellings of the $9^{\text {th }}-10^{\text {th }}$ centuries there are almost exclusively stone ovens, while in the dwellings of the $11^{\text {th }}-12^{\text {th }}$ centuries open fireplaces are predominant (Hanuliak 1989, p. 180 -212). This shift may have been caused by certain climatic fluctuations or by the temporary character of the dwellings.

11 The open fireplace could substitute almost all functions of the oven in a dwelling. Ethnographic observations show that fireplaces were used mostly for cooking (putting pots on the fire, hanging kettles over the fire or heating water by putting hot stones into them) (Plessingerová 1963, p. 209 -211, 183). The typical form of early medieval ceramics - a slim pot with a extension in the upper third of the pot's height (linked to the good absorption of heat), corresponds to the cooking in pots on the fire. Moreover, lighting up and heating the room were further important functions of the fireplace. It was seldom 
used for drying of agricultural products and quite frequently used for baking. Some cult and magic customs also played certain roles using of open fireplaces. They were considered as a symbol of home (Sopoliga 1983, p. 157).

\subsection{Covered fireplaces}

\subsubsection{Stone ovens}

Stone ovens in dwellings are the most frequent phenomenon in the early medieval settlements of south-western Slovakia (Fig. 1). They start to occur in Old Slavonic settlements and are a frequent element during the whole Middle Ages (Bialeková 1962, p. $97-148$, Habovštiak 1985, p. 87 - 100). Several authors have already pointed out the incorrectness of the name "stone hearth" (Dostál 1987, p. 17 -19). The theory of the gradual development of heating devices from open fireplaces to hearths (within the frame of the Slovak Middle Ages) is unambiguously unjustified today. This is clearly documented by the findings of stone ovens in Old Slavonic settlements (Bialeková 1962, p. 97 -148). The situation seems to be quite different: in fact there is an increasing number of open fireplaces in the Middle Ages.

Fig. 1 : The main types of ovens in early medieval dwelling : 1- stone ; 2 - clay oven ; 3- fireplace

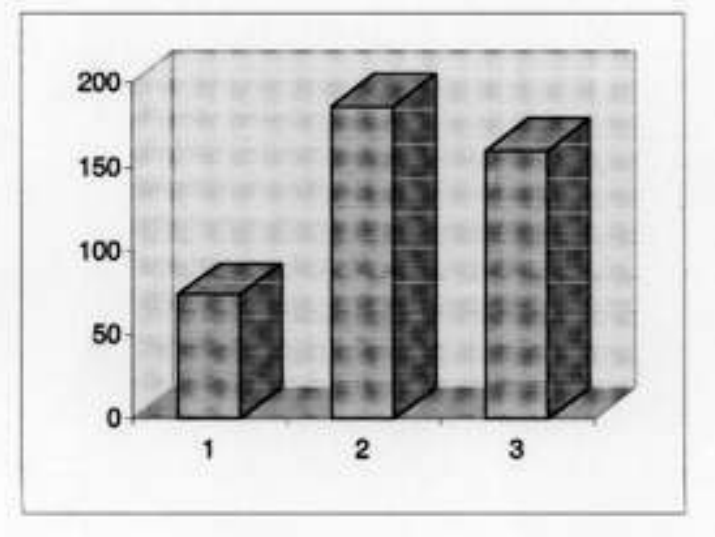

Stone ovens are most frequently built of quarry stone, though river pebbles and broken parts of querns were also often used. In the $9^{\text {th }}-12^{\text {th }}$ centuries ovens made of dry-laid stone (with smoke penetrating the gaps) occur most frequently in south-western Slovakia, the combination of stone and clay is rare. Ovens are built directly on the floor or in a shallow hollow, while positioning on an elevated clay base is rare. Ovens are usually placed in one of the corners of a dwelling, exceptionally in the centre or along one of the walls. In many cases it is difficult to decide whether there was a fireplace or whether it is a remnant left from a disassembled oven. This is most difficult for clay-lined burnt areas on the dwelling's floor. Two ovens in a dwelling or an oven with an open fireplace (Tocík 1963, Fig. 44) belong to the exceptional findings. The positioning of a stone oven outside the dwelling's outline is an isolated case (Bialeková 1962, Fig. 38).

The installation of chimney hoods - devices for the smoke evacuation - significantly contributed to the improvement of living conditions in medieval dwellings. Besides cleaner air it allowed to lower ceilings and in this way a new space under the roof was formed. 
15 At present there are several documents on the existence of such devices on the territory of south-western Slovakia in the early Middle Ages. They are proved by post-holes placed in the outline of a stone oven. The existence of a chimney hood is also considered by M. Hanuliak in Chæab (Hanuliak 1989, p. 158, Fig. 10). Archaeological findings do not provide any information concerning the upper part of chimney hoods. The ethnographic parallels suggest covering the upper parts with boards or wattle and lining them with clay (Sopoliga 1983, Fig. 11; Turzo 1979, p. 170).

16 The principal function of the stone oven was the heating of the room (Dostál 1975, p. 84), i. e. it was used mostly in winter. In summer the oven was more or less out of us (except for occasional baking). For everyday cooking it was more convenient to use an open fireplace (lower consumption of wood and lower heating of the room), which may have been placed in the dwelling together with the oven. Fireplaces situated outside of the dwelling must also have been used. It cannot be excluded that the stone oven itself could be used as a base for an open fire. Some stone ovens were used in various manufacturing operations (jewel-making etc.) (Hruby 1961, p. 492).

17 The archaeological literature generally accepts the heating function of the oven (Niederle 1953, p. 268, Skružny 1980, p. 225, Grimm 1969, p. 279-282, Tauber 1980, p. 262). Ethnographic investigations on one hand support the heating function (Pražák 1966, p. 321 -348, Švecová 1968, p. 149), on the other hand, quite opposite opinions also exist. Langer based himself on the testimonies of those who remembered conditions where the residential building was unheated for most of the winter (the oven was used only for baking bread), fire was made only for cooking and many members of the family used to sleep outside the residential room (in unheated chambers, hay-lofts and stables (Langer 1987, p. 240). For archaeology it is difficult to cope with these contradicting opinions. From ethnographic observations it is clear that in certain regions ovens were definitely used for heating. According to Švecová ovens were originally used for various functions (heating rooms, baking bread, cooking etc.) and only afterwards these functions were changed or individual functions were assumed by other devices (stove etc.), so that the oven was gradually transformed into an exclusive bread baking oven Švecová 1968, p. 149). The above-given information indicates the necessity of a very cautious utilization of the results provided by the ethnographic investigations from older periods (different social environment, different stages of development of individual devices, climatic changes (affluence or lack of fuel etc.). The archaeological situation seems to be more clear. For example, the investigation of the early medieval settlements in Bajë and in Muûla - «enkov (Cheben -Ruttkay 1995; Hanuliak-Kuzma 1988, p. 49-50) revealed a stone oven in almost every dwelling (rarely a clay oven or a fireplace was found) and the findings of isolated dome-shaped clay ovens positioned outside the dwellings are also frequent. As the stone ovens were not built from local stone, but from imported quarry stone (it was easy to transport the stone on rafts along the rivers), it is almost sure that they had a different function than the clay ones, the construction of which did not meet any impediments and must have been much simpler (in comparison with the transport of the quarry stone). It therefore appears that the stone oven and the clay oven did not have the same function (and for some reason - better heating efficiency? - the more complicated of the two was given the priority). 
Fig. 2 : Chotin - dwelling with a multifunctional clay oven

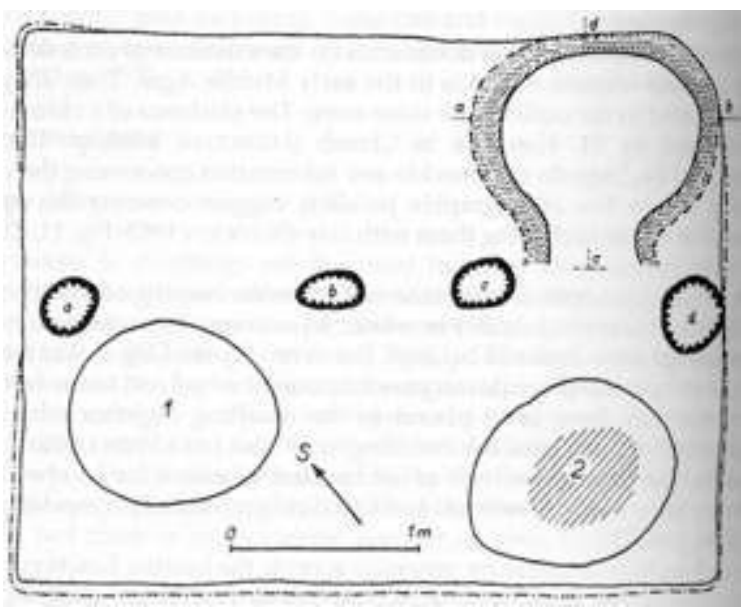

\subsubsection{Clay ovens}

In the dwellings, but also outside them, dome-shaped clay ovens are found very frequently. On the territory of south-western Slovakia they are documented as early as the $7^{\text {th }}$ century as in Bajc.

According to their position they can be divided in ovens : a) directly connected with the dwelling (Fig. 2), b) situated out of the dwelling (Fig. 3). The findings discovered so far do not always allow to distinguish residential buildings from manufacturing/working houses (Fodor 1986, p. 186 -193).

Fig. 3 : Bajc - isolated bread-baking clay oven

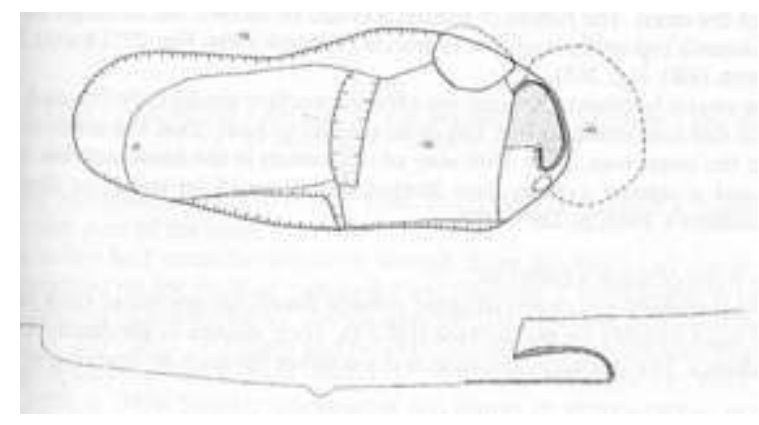

\section{a. Clay oven in a dwelling}


22 A dome-shaped clay oven from Slaûany is so far unique. On the top of its dome there is a firmly built-in clay pan (Ruttkay 1992). Similar findings are known from Moravia (Dostál 1987, p. 19) and from eastern Europe (Rappoport 1975, p. 152, Fig. 55). In these cases L. Skružny suggests not only the pronounced drying function, but also the function of an elevated open fireplace made on the pan (Skružny 1980, p. 226). Here meals were cooked in a more convenient way. In this connection it is worth mentioning the findings of clay pans in the locality of Bajc. In several cases, deep imprints of wooden beams were discovered on the bottom, which suggests that the pans were fixed to a wooden structure. It may have been that the pan fixed to a structure like this was used as an elevated base for an open fireplace. Fireplaces on wooden structures used to be a frequent element of the folk architecture (Plessingerová 1963, p. 158 -160).

The oven (2) sunk into the subsurface (within the dwelling or positioned outside it) could not perform the heating function (the layer of clay over the oven was a perfect thermal isolation). This was the reason why the ovens were sunk into the subsurface, and in this way the resistance of the oven against the changes of weather was also increased. With the externally placed ovens it was possible to draw the fumes out of the residential room. The bottom of the oven was modified in many ways to improve thermoisolating properties (the same is the case with clay ovens of type 1). Below the clay bottom, various materials were found, often in combinations (sand, gravel, bigger stones, shards). These layers, among others, elevated the bottom of the oven over the floor, which allowed more convenient utilization of the oven. The fumes of the oven could be drawn out through the opening on the dome's top or through the entrance (Teodor 1984, Fig. 27 ; Dostál 1975, Fig. 11 ; Tauber 1980, Fig. 265).

The ovens horizontally sunk into the subsurface could only be used in such a way that fire was made inside, the oven was let to heat, then the ashes were raked out and the oven was used. This way of utilization is the most suitable for baking bread and a similar system (less heated oven) could be used for drying fruits (Plessingerová 1963, p. 187 -189).

\section{b. Clay oven outside a dwelling}

The dome-shaped clay ovens situated outside dwellings are either sunk into the terrain or built directly on the surface (Fig. 4). Their design is similar to those found in dwellings. The smoke evacuation is done either through an opening in the dome, through the increased main hole (Tocík 1980, Fig. 153 :1) or through a chimney placed in the rear part of the oven. 
Fig. 4 : Typological classification of isolated ovens

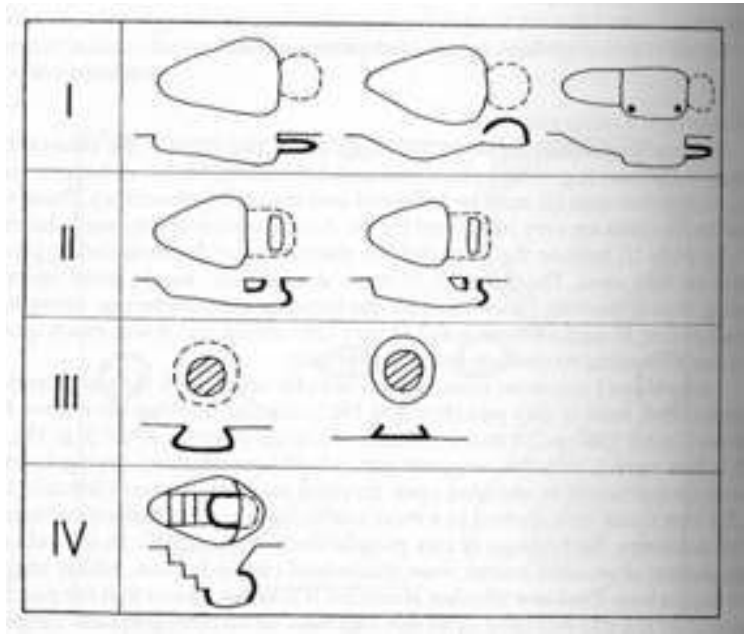

Fig. 5 : Vel'ky Cetin - dwelling with a fire place (or a disassembled stone oven) and a clay oven for bread-baking (VIIth cent.)

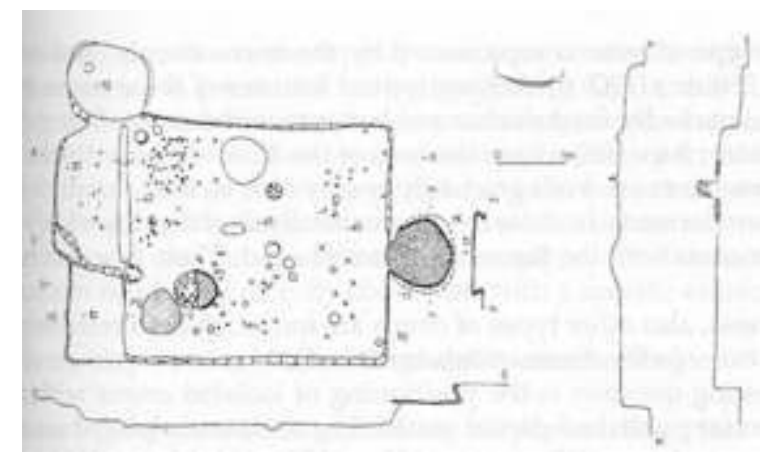

These ovens had versatile functions, though these functions can rarely be precisely determined on the basis of archaeological findings. I. Méri suggests respectively the functions of baking bread, drying agricultural products and smoking meat (Méri 1963, p. 273 -281). N. Páradi and others document firing ceramics in isolated dome-shaped clay ovens (Páradi 1982-3, p. 211 -218, Veselinovic 1953, p. 55, Gajewski 1959, s. 343). Similar documents are found in ethnographic materials (Pražák 1958, p. 78 -81). There are also traces of different activities carried out in these ovens (e.g. baking bread) (Habovštiak 1985, p. 103) which makes precise determination of the oven's function difficult and in many cases impossible (some of the ovens may have been multifunctional).

A special type of oven is represented by the ovens deeply sunk into the subsurface $(150-250 \mathrm{~cm})$ (Fig. 6). Among typical features of these ovens belong step-like entrances, markedly fired domes and bottoms without clay lining. This type is so far known from 8 localities from the turn of the $12^{\text {th }}-13^{\text {th }}$ centuries (sometimes there are successive ovens built gradually one by one, so that complete manufacturing batteries are formed). In these ovens we usually find thin layers of wooden cinders in combination with the layers of lime and sand. Their function has not been clarified yet. 
Fig. 6 : Nitra- Parovské Haje - a network of ovens of unknown purpose

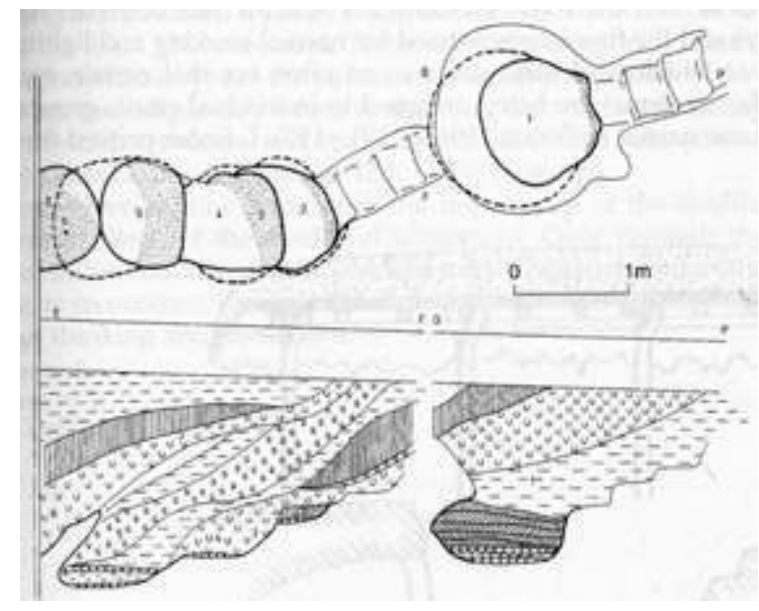

Besides these, also other types of ovens are found, though relatively rarely, but their analysis exceeds the frame of this contribution.

An interesting question is the positioning of isolated ovens within the settlement. In the so-far published partial works they are mostly placed on the periphery of the settlement's area (Hanuliak 1989, p. 159 -160, Minác 1980, p. $487-496$ ). Here it is necessary to point out the fact that in most cases the localities in question were only partially investigated and it is therefore impossible to determine the position of ovens with regard to the whole settlement. More extensive terrain investigations from recent years (Mužla-Cenkov, Bajc) show the positioning of ovens outside dwellings. The analogies with this way of positioning the ovens are also documented in the ethnographic material (Bednárik 1943, p. 139 -179). It is necessary to take into consideration that in these cases the ovens are common ones and they are not extensive devices connected only with craftsmanship. An accidental fire of such an oven could not mean a significant threat, neither to the settlement as a whole, nor to the adjacent dwellings.

It is interesting that even amongst the thoroughly investigated early medieval settlements in the Carpathian Basin it is possible to find some where the isolated ovens are completely absent, i. e. their functions were probably performed by the ovens in dwellings. In Hungary, in the locality of Doboz $\left(10^{\text {th }}-12^{\text {th }}\right.$ centuries $)$ no isolated ovens occur, but almost in every semi-underground house there is a dome-like clay oven in the corner and an open fireplace in the centre (Kovalovski 1975, p. 223). It is clear that the oven performed a specific function (baking or heating respectively) and the fireplace was used for normal cooking and lighting the room. 
Fig. 7 : Reconstruction of an isolated oven, (by I. Fodor)

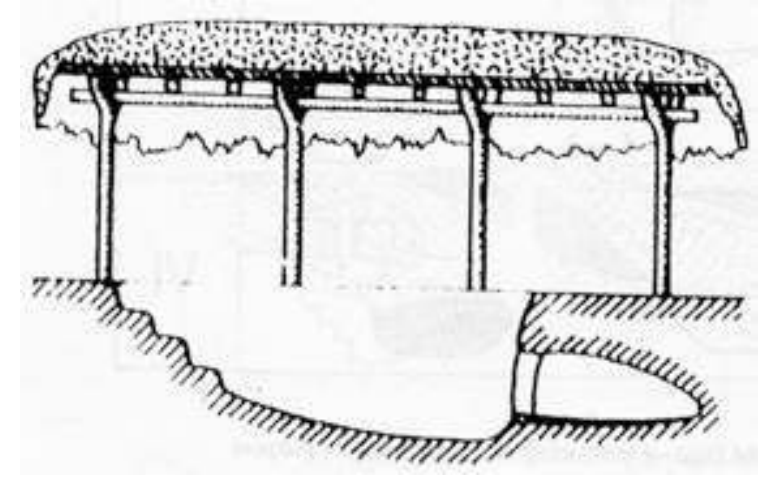

In the archaeological literature we can often see that certain types of ovens (made of clay or stone) are being assigned to individual ethnic groups (these opinions are summarized in Fodor 1986, p. 191 -192). I. Fodor proved the unreality of such theories and he connects the type of oven (clay or stone) with the occurrence of the given material in particular territories $(1986,192)$. In this connection it is necessary to mention the frequent occurrence of stone ovens made of quarry stone in regions which are poor in this type of stone (southern part of south-western Slovakia), which means that the stone must have been imported there. The type of stone used for building the oven thus may have been connected with the oven's specific function or it may have reflected certain cultural traditions of the builders and this does not need to be directly connected with a specific ethnic group.

\subsection{Stone oven, clay oven and open fireplace in one dwelling}

In the above given connections there are very interesting cases where a stone oven situated in the corner of a dwelling, a clay oven hollowed into a wall and occasionally also an open fireplace occur together. Such cases are found as early as the turn of the $6^{\text {th }}-7^{\text {th }}$ centuries (Vel'ky Cetín, Fig. 5) and more frequently in the $9^{\text {th }}-10^{\text {th }}$ centuries - MužlaCenkov - (Hanuliak - Kuzma - Šalkovsky 1993, p. ), Bajc (Ruttkay 1996), Štúrovo - Obidská puszta (Ožd'áni 1985, s. 182 -184), Patince (Cheben 1988), Komjatice (Tocík 1979, p. 246 -272), IIIa (information obtained thanks to J. Rajtár). Their occurrence decreases again in the $11^{\text {th }}-13^{\text {th }}$ centuries. Similar situations were discovered on the Balkan peninsula and in the Ukraine (Teodor 1984). An interesting situation was discovered in the locality of Dobosz (Hungary) where almost in every dwelling there is a clay oven situated in the corner and an open fireplace in the centre. This proves that each of these devices had a different function (e. g. the clay oven was used for baking bread, the stone one for heating and the open fireplace for everyday cooking).

\section{Dating and conclusions}

The dating of individual types of firing devices shows that most of them were used during the $6^{\text {th }}-12^{\text {th }}$ centuries. There are differences in the intensity of the occurrence of individual types - the stone ovens are most frequently used in the $6^{\text {th }}-10^{\text {th }}$ centuries, the simple clay ovens in the $9^{\text {th }}-12^{\text {th }}$ centuries, the open fireplaces in the $11^{\text {th }}-13^{\text {th }}$ centuries, 
and the ovens sunk into the subsurface (horizontal and oblique) almost exclusively in the $12^{\text {th }}-13^{\text {th }}$ centuries.

The above-given outline underlines the importance of the detailed study of individual components of the medieval settlement. Only through the thorough knowledge of individual details is it possible to put together the faithful and complete picture, to reconstruct the way of life of medieval man and to understand better his way of thinking and his actions.

\section{BIBLIOGRAPHIE}

BEDNÁRIK, R. 1943. Hmotná kultúra slovanského æudu, In : Slovenská vlastiveda II. Bratislava 1943, p. 139-179.

BIALEKOVÁ, D. 1962a. Nové vcasnoslovanské nálezy na juhozápadnom Slovensku. Slov. Archeol., 10, p. $97-148$.

CHEBEN, I. 1987. Vysledky záchranného vyskumu v Patinciach. Šúdijné zvesti AÚ SAV v Nitre, p. 307-329.

CHEBEN, I. RUTTKAY, M. 1995. Šiesta sezóna záchranného vyskumu v Bajci. In : Archeol. Vysk. a Nál. na Slov. v r. 1993, Nitra, p. 66-67.

DOSTÁL, B. 1975. Bfieclav-Pohansko IV, Vecekomoravsky vecemožsky dvorec. Brno.

DOSTÁL, B. . 1987. Obytné zemnice z fiemeslnického areálu Bfieclavi-Pohanska. In : Sborník prací FFBU , E 32, 1987, p. 63-109.

FODOR, I. 1986. Vostocnyje paralely pecej vne žilišc na drevnevengerskich poselenach, Acta Arch. Hung 38, p. 185-193.

GAJEWSKI, L. 1959. Materialy do srednioviecznego garncarstva wiejskiego v Malopolsce. In : Mater, Archeol,I.Krakow, p. 343-351.

GRIMM, O. 1969. Zum Ofen in der frühmittelalterlicher Archäologie, Archäologisches zu nieder. Döns, bairisch Türnitz, Ruf, 16, p. 279-282.

HABOVŠTIAK, A. 1985. Stredoveká dedina na Slovensku. Bratislava.

HANULIAK, M. 1989. Praveké, vcasnostredoveké a stredoveké osídlenie v Chæabe. Slovenská archeológia XXXVII, p. 151-212.

HANULIAK, M..-Kuzma, I. 1988. Ôsma sezóna vyskumu v Mužli-Cenkove. AVANS v r. 1987, p. 49-50. HRUBY, V. 1961. Pfiispevok k poznání velkomoravského obydlí. Pam. Arch. 52, p. 488-495.

KOVALOVSZKI, J. 1975. Elözetes jelentés a dobozi Árpád-kori faluásatásról 1962-1974. Archeol. Ért., 102, p. 204-223.

LANGER, J. 1987. Pfiispevok k typologii topeništ'. Arch. Hist. 12, p. 233-244.

MÉRI, I. 1963. Árpád-kori épitkezésünk feltárt emlékei Orosháza határában. Rég. Füz, Ser, II, No. 14, Budapest. 
NIEDERLE, L. 1953. Rukoväù slovanskych starol̈itnosti. Praha.

OŽDÁNI, D. 1985. Vyslkedky záchranného vyskumu v Štúrove v Obidskej pust. In : Archeol. Vysk. a Nál. na Slov. v r. 1984. Nitra, p. 182-184.

PARÁDI, N. 1982-1983. Keramikfunde. In : Paradi, N.-Holl, I : Die Erforschung des mittelalterlichen Dorfes Nagykeszi. Mitt. Arch. Ins.: 12-13, p. 211-218.

PITTEROVÁ, A. 1971. Dum a sídlište zemedelského charakteru v 6.-15. století na území CSSR. In : Zaniklé stfiedoveké vesnice v CSSR ve svetle archeologickych vyzkumü, díl I, p. 11-18, Uherské Hradi_tï. PLESSINGEROVÁ, A. 1963. Vyvoj topenište, jeho využívaní a vyznam ve slovanskych obcích pod Javorníky. In : SNM v Praze, A-Historie, p. 149-235.

PRAŽÁK, V. 1958. Hrncífiství v semipalatinské oblasti západní Sibie pocátkem 20. století. Ces. lid. 45, p. $78-81$.

RAPPOPORT, P.A. 1975. Drevnerusskoe Ïiližce. Leningrad.

RUTTKAY, M. 1989. Vyskum stredovekého osídlenia v Bajci. Arch. historica. 14, p. 299-310.

RUTTKAY, M. 1990. Pece na ranostredovekych sídliskách juhozápa-dného Slovenska. Arch. historica 15, Brno 1990, p. 337-348.

SOPOLIGA, M. 1983. Ohniskové zariadenie v ํoudovom obydlí vo vychodoslovensko-ukrajinskopoํoskej kontaktnej oblasti. In : Zbor. Slov. Nár. Múzea - Etnografia 24, p. 157-178.

SKRUŽNY, L. 1980. Nekolik poznámek k otázce vyvoje a funkce pece ve slovanskych, stfiedovžkych a novovekych objektech i mimo ne. Arch. Historica 5, p. 221-242.

ŠveCoVÁ, S. 1968. Ohništia na juhozápadnom Slovensku /I. casÈ/. I : Zbor. Slov. Nár. Múzea Etnografia 9, p. 119-166.

TAUBER, J. 1980. Herd und Ofen im Mittelalter. Untersuchungen zur Kulturgeschichte am archäologischen Material vornehmlich der Nordwestschweiz. Olten und Freiburg.

Tocík, A. 1963. Súcasny stav dádania najstarších dejín slovenského národa. Archeol. Rozhl., 15, p. 591-624.

тосі́к, A. 1980. Vysledky prieskumu archeologickych lokalít na juhozápadnom Slovensku. In : Archeol. Vysk. a Nál. na Slov. v r. 1978. Nitra, p. 266-272.

TURZo, J. 1979. Lokálnem dobové formy ohnísk regiónu Kysuce-Podjavorníky v múzeu slovenskej dediny In : Zbor. Slov. Nár. Múzea LXXIII - Etnografia 20, p. 167-195.

VESELINOVIC, R. L. 1953. Starosrpsko nasele na Bostaništu kod Mošorina u Backoj. Rad vojvodjanskuh muzeja, 2. Novi Sad, p. 5-58.

\section{RÉSUMÉS}

Plusieurs types de dispositifs de chauffe comptent parmi les découvertes fréquentes dans les habitats du Haut Moyen-âge du sud-ouest de la Slovaquie. Différents types peuvent être trouvés ensemble, ce qui rend nécessaire une compréhension qui tient compte de leur relation. Une interprétation plus précise de leur fonction et de leur évolution contribue à la reconstitution du mode de vie médiéval. Le grand nombre de découvertes permet de retracer les changements du 6e au 13e siècles. Dans les habitats du sud-ouest de la Slovaquie, deux groupes principaux de dispositif de chauffe existaient au Haut Moyen-âge : les fours, c.à.d. des foyers couverts fait de 
pierre, d'argile ou d'une combinaison des deux, et les foyers, c.à.d. des restes d'un feu ouvert. Chacun de ces deux groupes peut être subdivisé selon la construction, la fonction, la position à l'intérieur ou à l'extérieur du bâtiment ou dans l'habitat. L'emplacement du dispositif de chauffe était lié à sa fonction et, en grande partie, à la tradition. Ici la comparaison avec les données éthnographiques de Slovaquie sont d'un grand secours.

Among the frequent findings in the settlements of the early Middle Ages in South-West Slovakia belong different types of heating devices. Different types are often found together and this means that it is necessary to assess them in mutual correlation. A more detailed understanding of their function and development is a contribution to the elucidation of the way of life of the medieval people. The important number of findings allows us to trace the changes from the $6^{\text {th }}$ to the $13^{\text {th }}$ centuries. In the settlements of South-Western Slovakia two principal groups of heating devices occurred in the early Middle Ages : ovens, i. e. covered fireplaces made of stone, clay or a combination of the two, and open fireplaces, i. e. the remnants of an open fire. Each of these two groups can be further divided according to the construction, function and position inside or outside the object or within the settlement. The positioning of a heating device in a settlement object was conditioned by its function and also, to a large extent, by tradition. Here the comparison with ethnographical data of Slovakia provides important hints.

\section{INDEX}

Mots-clés : Fours, foyers, haut Moyen âge, Slovaquie

Keywords : Ovens, healths, early Middle Age, Slovakia

\section{AUTEUR}

\section{MATEJ RUTTKAY}

Archeologicky Ustav SAV, Nitra, Slovakia 